ORIGINAL ARTICLE

\title{
Vitamin C stability in acerola and \\ camu-camu powder obtained by \\ spray drying
}

\section{Estabilidade da vitamina $C$ em pós de acerola e \\ camu-camu obtidos por spray drying}

\author{
Vitor Augusto dos Santos Garcia1 (D), Josiane Gonçalves Borges ${ }^{1}$, \\ Fernanda Maria Vanin ${ }^{1}$, Rosemary Aparecida de Carvalho ${ }^{1^{*}}$
}

${ }^{1}$ Universidade de São Paulo (USP), Faculdade de Zootecnia e Engenharia de Alimentos, Pirassununga/SP - Brasil

${ }^{*}$ Corresponding Author: Rosemary Aparecida de Carvalho, Universidade de São Paulo, Faculdade de Zootecnia e Engenharia de Alimentos, Av. Duque de Caxias Norte, 225, CEP: 13635-900, Pirassununga/SP - Brasil, e-mail: rosecarvalho@usp.br

Cite as: Garcia, V. A. S., Borges, J. G., Vanin, F. M., \& Carvalho R. A. (2020). Vitamin C stability in acerola and camu-camu powder obtained by spray drying. Brazilian Journal of Food Technology, 23, e2019237.

https://doi.org/10.1590/1981-6723.23719

\begin{abstract}
Acerola and camu-camu fruits possess high vitamin $\mathrm{C}$ content. However, since these fruits are little consumed in their fresh form, it is important to consider that vitamin $C$ can be oxidized depending on storage conditions. Thus, this study aimed to produce acerola and camu-camu powders by spray drying to maintain the stability of their vitamin $\mathrm{C}$ content during storage. Acerola and camu-camu powders were characterized in relation to their physicochemical characteristics, antioxidant activity, and vitamin $\mathrm{C}$ concentration and stability under different storage conditions $\left(30^{\circ} \mathrm{C}\right.$ and $40{ }^{\circ} \mathrm{C}, 75 \%$ relative humidity). In general, the powders were proven to be stable, with low water activity $(<0.40)$ and humidity $(<4.0 \mathrm{~g} / 100 \mathrm{~g}$ powder), as well as high vitamin C concentrations $(1593.2$ and $6690.4 \mathrm{mg} / 100 \mathrm{~g}$ of powder for acerola and camu-camu, respectively). Furthermore, we observed a high antioxidant activity by ABTS ${ }^{\bullet}$, DPPH $\bullet$ and FRAP assays. The powders stored at lower temperature $\left(30^{\circ} \mathrm{C}\right)$ showed higher vitamin $\mathrm{C}$ stability. In conclusion, acerola and camu-camu powders produced by spray drying are potential sources of vitamin $\mathrm{C}$ and active compounds and are therefore suitable for several food industry applications.
\end{abstract}

Keywords: Stability; Active compounds; Ascorbic acid; Powder.

\section{Resumo}

Frutos de acerola e camu-camu possuem alto teor de vitamina $C$ que, no entanto, pode ser oxidada, dependendo das formas de armazenamento e normalmente os frutos são pouco consumidos na sua forma in natura. Desta forma, o presente estudo teve como objetivo produzir pó de acerola e camu-camu por secagem em spray dryer para manter a estabilidade da vitamina $\mathrm{C}$ durante o armazenamento. Os pós de acerola e camu-camu foram caracterizados em relação às suas características fisicoquímicas, atividade antioxidante, concentração de vitamina $C$ e estabilidade, em diferentes condições de armazenamento $\left(30{ }^{\circ} \mathrm{C}\right.$ e $40{ }^{\circ} \mathrm{C}, 75 \%$ de umidade relativa). Em geral, os pós foram considerados estáveis, com baixa atividade de água $(<0,40)$ e umidade $(<4,0 \mathrm{~g} / 100 \mathrm{~g}$ de pó), além de alta concentração de vitamina C (1593,2 e 6690,4 mg / $100 \mathrm{~g}$ de pó para acerola e camu-camu, respectivamente). 
Além disso, uma alta atividade antioxidante foi observada pelos ensaios ABTS ${ }^{\bullet+}$, DPPH ${ }^{\bullet}$ e FRAP. Os pós armazenados em menor temperatura $\left(30^{\circ} \mathrm{C}\right)$ apresentaram maior estabilidade em relação à vitamina $\mathrm{C}$. Assim, pode-se concluir que os pós de acerola e camu-camu produzidos pela secagem por spray dryer são fontes potenciais de vitamina $C$ e compostos ativos, podendo ser utilizados para diferentes aplicações na indústria de alimentos.

Palavras-chave: Estabilidade; Compostos ativos; Ácido ascórbico; Pó.

\section{Introduction}

Vitamin C participates in several biological functions, such as enhancing collagen formation (Findik et al., 2016), and is considered one of the principal vitamins required by the human body due to its antioxidant properties (Padayatty \& Levine, 2016; Podmore et al., 1998). Indeed, the increased intake of antioxidants has been associated with a lower risk of cardiovascular disease (Ellingsen et al., 2009). However, due to its sensitivity to variations in temperature, $\mathrm{pH}$, oxygen concentration and light intensity (Fennema et al., 2010), vitamin C is considered unstable (Marques et al., 2009), which limits its application range (Han et al., 2012).

Acerola and camu-camu have been receiving special attention thanks to their high vitamin $\mathrm{C}$ concentrations. Acerola (Malpighia emarginata DC) originates from Central and Northern South America and has been grown in large areas of Brazil (Malegori et al., 2017). It has been reported to contain numerous active compounds, such as vitamin A, carotenoids (Fernandes et al., 2019), anthocyanins (Rezende et al., 2018), flavonoids, and phenolic compounds (Silva et al., 2016), as well as vitamin C (Brito et al., 2007; Mercali et al., 2012; Müller et al., 2010; Rufino et al., 2010). Consequently, it is used in the fabrication of numerous industrialized products, such as pulps, juices, jellies, and others. Usually, the incorporation of acerola into commercial products occurs for use as dietary supplements to increase the immune response, as well as for its antioxidant potential and nutritional properties (Belwal et al., 2018).

Little known in the rest of Brazil, camu-camu (Myrciaria dubia) was identified in the Amazon rainforest (Azevêdo et al., 2014). Differently from acerola, several studies report that camu-camu is not consumed in natura due to its acidic taste (Azevêdo et al., 2014, 2015; Neves et al., 2015). Camu-camu possesses even higher vitamin C content than acerola (Azevêdo et al., 2014; Fujita et al., 2017; Neves et al., 2015) and is widely used for the fabrication of industrial products such as sherbet and purees and exported, mainly to Japan and the European Union, in the form of pulp, extract, or juice (Akter et al., 2011). Similar to what has been reported for acerola, in addition to its high vitamin $\mathrm{C}$ content, camu-camu (fruit, pulp, residues) also presents phenolic compounds (Fidelis et al., 2018), carotenoids, and proanthocyanidins (Azevêdo et al., 2014).

Acerola and camu-camu are highly perishable fruits, which renders their commercialization difficult (Fujita et al., 2013; Fujita et al., 2017; Malegori et al., 2017; Pereira et al., 2014). In fact, fresh acerola fruits rarely are exported (Malegori et al., 2017), while camu-camu has a complex and expensive transport chain (Fujita et al., 2013). Thus, the production of dehydrated or spray dried products is an interesting alternative.

Fidelis et al. (2019) reported that the extract obtained from the camu-camu seeds under magnetic stirring showed antioxidant activity in vitro, antimicrobial, anti-hypertensive, anti-hemolytic and anti-hyperglycemic effects, which may be a possible technological use in the development of functional foods. Microparticles of microencapsulated acerola pulp and residue showed good antioxidant activity, as well as presence of phenolic compounds and flavonoids (Rezende et al., 2018).

According to Sagar \& Suresh Kumar (2010), spray drying yields high quality powders, with good reconstitution characteristics, low water activity, as well as good storage suitability (Bhusari et al., 2014), and possible microencapsulation of the active compounds. Microencapsulation of chemically sensitive substances by spray drying has proven viable for producing dehydrated juices by concentrating the typical 
active substances and protecting them in a polymeric matrix against oxidation, especially for unstable substances such as ascorbic acid present in acerola (Santos et al., 2014).

Thus, this study aimed at producing and characterizing acerola and camu-camu powders through spray drying, evaluating their antioxidant activity by different methods, and determining the stability of their vitamin $\mathrm{C}$ levels during storage.

\section{Materials and methods}

\subsection{Materials}

We produced the powders using acerola pulp obtained from DeMarchi (Campinas, São Paulo, Brazil), camu-camu pulp donated by EMBRAPA (Boa Vista, Roraíma, Brazil), and maltodextrin (DE 12, Corn Products, Mogi Guaçu, SP). The pulps were kept frozen (Brastemp Flex, BVR28HBBNA) until use. We used ascorbic acid (Synth) as a standard for vitamin $\mathrm{C}$ analysis. The antioxidant activity assays included ABTS $^{\bullet+}$ (2,2'-azino-bis(3-ethylbenzothiazoline-6-sulfonic acid), Sigma Aldrich), potassium persulfate (Synth), DPPH• (2,2-diphenyl-1-picrylhydrazyl, Sigma Aldrich), trolox (6-hydroxy-2,5,7,8tetramethylchromane-2-carboxylic acid, Sigma Aldrich), TPTZ (2,4,6-Tris(2-pyridyl)-s-triazine, Sigma Aldrich), iron sulfate heptahydrate (Synth), and ferric chloride hexahydrate (Synth).

\subsection{Production of acerola and camu-camu powders}

The camu-camu fruits were washed with running water to remove dirt and pulped at EMBRAPA - Boa Vista (RR). The pulping was performed in a horizontal stainless steel pulping machine (COMPACTA) with a $1 \mathrm{~mm}$ diameter sieve. Immediately afterwards, the camu-camu pulp was packed in low-density polyethylene bags (approximately $800 \mathrm{~g}$ ) and frozen. The pulp of was pasteurized at $90{ }^{\circ} \mathrm{C}$ for $60 \mathrm{~s}$, according to Bastos et al. (2008).

To produce the powders, acerola and camu-camu pulps were kept refrigerated $\left(5 \pm 2{ }^{\circ} \mathrm{C}\right)$ and thawed before drying. For acerola powder production, $5 \%$ of maltodextrin was added to the pulp and the mixture was homogenized under mechanical stirring (500 rpm, IKA RW20, USA) for 30 minutes. Drying was carried out in a MSD 5.0 spray dryer (Labmaq, Brazil), with a $2.0 \mathrm{~mm}$ diameter injector nozzle, using a peristaltic pump (Masterflex - LS, USA) for feeding, an inlet temperature of $120^{\circ} \mathrm{C}$, an outlet temperature of $80^{\circ} \mathrm{C}$, and a flow rate fixed at $20 \mathrm{~mL} / \mathrm{min}$ (Righetto \& Maria Netto, 2005).

The camu-camu powder was produced according to the method proposed by Dib Taxi et al. (2003), with $15 \%$ maltodextrin added to the pulp under mechanical stirring (500 rpm, IKA RW20, USA) for 30 minutes. For spray drying, feeding was performed using a peristaltic pump (Masterflex - LS, USA), with a flow rate of $20 \mathrm{~mL} / \mathrm{min}$, an inlet temperature of $150{ }^{\circ} \mathrm{C}$, and an outlet temperature of $95^{\circ} \mathrm{C}$.

After production, acerola and camu-camu powders were stored in amber glass bottles for further analysis.

\subsection{Pulp and powders characterization}

\subsubsection{Determination of vitamin C concentration}

Vitamin $\mathrm{C}$ concentration was determined using a high-performance liquid chromatograph (Shimadzu, Prominence), equipped with a Res Elut C18 (VP-ODS) column. Samples (for pulp acerola and camu-camu, $0.4 \%$ to $4.1 \%(\mathrm{w} / \mathrm{w})$ for acerola powder and $3.7 \%$ to $8.7 \%(\mathrm{w} / \mathrm{w})$ for camu-camu powder) were solubilized in acidified ultrapure water $(\mathrm{pH}=2.5$ using $50 \mathrm{mM}$ phosphoric acid) and kept for 10 minutes in an ultrasonic bath (Ultra Clear, $1400 \mathrm{~A}$, Unique), before being filtered through a $0.45 \mu \mathrm{M}$ nylon filter (Millex). As mobile phase, acidified ultrapure water $(\mathrm{pH}=2.5, \mathrm{pH}$ adjusted using phosphoric acid with concentration at $50 \mathrm{mM})$ 
was used, with a flow rate of $1.0 \mathrm{~mL} / \mathrm{min}$. We injected $20 \mu \mathrm{L}$ of the sample and the detection was performed at $254 \mathrm{~nm}$.

\subsubsection{Color parameters in pulp and powders}

The color parameters ( $L^{*}=$ luminosity, $a^{*}=$ chroma $a^{*}$ and $b^{*}=$ chroma $b^{*}$ ) of samples (pulp and powder) in quartz vessels were determined using a Miniscan XE (HunterLab, illuminant D65) colorimeter controlled by Universal Software.

\subsection{Powder characterization}

\subsubsection{Hygroscopicity}

For the hygroscopicity determination, powder samples $(0.1 \mathrm{~g}$ acerola or camu-camu $)$ were stored in desiccators containing saturated sodium sulfate solution (Anidrol, 81\% relative humidity) and kept at $25 \pm 2$ ${ }^{\circ} \mathrm{C}$ (Incubator Biochemical Oxygen Demand - BOD, Marconi-MA415) for 7 days (Cai \& Corke, 2000). After this period, sample mass was determined using an analytical balance (Shimadzu - AUY 220) and hygroscopicity was calculated as $\mathrm{g}$ of absorbed water/100 $\mathrm{g}$ of dry matter.

\subsubsection{Water activity}

An Aqualab 3 analyzer (Decagon Devices, USA) was used to determine water activity at $25 \pm 2{ }^{\circ} \mathrm{C}$.

\subsubsection{Moisture content}

Moisture content was determined using an Ohaus - MB 35 moisture analyzer, with infrared radiation from a halogen source. For the analysis, $2 \mathrm{~g}$ of each sample (acerola and camu-camu powders) were used.

\subsubsection{Scanning electron microscopy (SEM)}

The powders' morphology was evaluated using a scanning electron microscope (Model TM300, Tabletop Microscope Hitachi, Japan). Prior to the analysis, powders were stored for a period of 10 days in desiccators containing silica gel. They then were deposited on double-sided carbon tape (Ted Pella) and fixed in aluminum probes. The images were obtained with an acceleration of $5 \mathrm{kV}$ and a magnification of $500 \mathrm{x}$.

\subsection{Antioxidant capacity assays}

\subsubsection{ABTS assay}

Antioxidant activity was determined using the $\mathrm{ABTS}^{\bullet+}$ method according to Re et al. (1999). The ABTS radical was generated by the reaction of the solution of $7 \mathrm{mM} \mathrm{ABTS}^{\bullet+}$ with potassium persulfate $(2.45 \mathrm{mM})$ in the absence of light for 16 hours. The solution was diluted (ethanol) and the absorbance determined using a spectrophotometer (Perkin Elmer, Lambda 35) at $734 \mathrm{~nm}$, until reaching a value of 0.7. Samples (0.01 g of powder) were solubilized in water ( $10 \mathrm{~mL}$ volumetric flask), and kept in an ultrasonic bath (Ultra Clear, 1400 A, Unique) for 10 minutes, after which $30 \mu \mathrm{L}$ of this solution was added to $3 \mathrm{~mL}$ of the free ABTS radical. The samples were maintained in the absence of light (6 minutes) and absorbance determined at $734 \mathrm{~nm}$, with the results expressed in $\mu \mathrm{M}$ trolox equivalent/g powder. 


\subsubsection{DPPH・assay}

The DPPH assay was performed according to the method proposed by Brand-Williams et al. (1995). Samples ( $0.2 \mathrm{~g}$ acerola or camu-camu powder) were solubilized in distilled water (50 $\mathrm{mL}$ volumetric flask) and from these, 8 dilutions were prepared. Aliquots $(100 \mu \mathrm{L})$ of each dilution were added to $3.9 \mathrm{~mL}$ of DPPH• solution $(0.2 \mathrm{mM}$ absorbance adjusted to 0.7 at $517 \mathrm{~nm})$ and absorbance was determined at $517 \mathrm{~nm}$ using a spectrophotometer (Perkin Elmer, Lambda 35) after 65 minutes of reaction. The antioxidant activity was expressed as the amount of antioxidant compounds required to reduce the initial concentration of $\mathrm{DPPH} \bullet$ to $50 \%\left(\mathrm{EC}_{50}\right)$.

\subsubsection{FRAP assay}

Antioxidant activity was determined and FRAP reagent was prepared according to the method proposed by Benzie \& Strain (1996). Samples (0.1 g acerola or camu-camu powder) were solubilized in distilled water (10 mL volumetric flask) and kept in an ultrasonic bath (Ultra Clear, $1400 \mathrm{~A}$, Unique) for 10 minutes. Then, $50 \mu \mathrm{L}$ of this solution was added to $2.850 \mu \mathrm{L}$ of FRAP reagent and maintained at $37^{\circ} \mathrm{C}$ in a thermostatically controlled bath (Marconi, MA-127) for 30 minutes. The absorbance of the solution was determined using a spectrophotometer (Perkin Elmer, Lambda 35) at $593 \mathrm{~nm}$ and the antioxidant activity was expressed in $\mu \mathrm{Mol}$ of trolox equivalent/g of powder.

\subsection{Stability assessment}

The powders' stability (acerola and camu-camu) was evaluated in terms of vitamin C concentration. The acerola and camu-camu powders were stored in desiccators (saturated sodium chloride solution, $75 \%$ relative humidity) in BOD (Incubator Biochemical Oxygen Demand, Marconi, MA415) at 30 or $40{ }^{\circ} \mathrm{C}$ (Daud et al, 2011). Before analysis, samples were solubilized in ultrapure water (pH 2.5 using $50 \mathrm{mM}$ phosphoric acid) with concentrations between $0.3-0.5 \%(\mathrm{w} / \mathrm{w})$ for pulp acerola and camu-camu, $0.4 \%$ to $4.1 \%(\mathrm{w} / \mathrm{w})$ for acerola powder and $3.7 \%$ to $8.7 \%(\mathrm{w} / \mathrm{w})$ for camu-camu powder. The solubilized samples were kept in an ultrasonic bath (Ultra Clear, $1400 \mathrm{~A}$, Unique) for 10 minutes, before the solution was filtered (Nylon $0.45 \mu \mathrm{M}$ - Millex). Vitamin $\mathrm{C}$ concentration was determined as described in 2.3.1. The degradation kinetics of vitamin $\mathrm{C}$ were evaluated using the 1st order model (Vikram et al., 2005) as shown in Equation 1.

$\ln \mathrm{C}=\ln \mathrm{C}_{\mathrm{o}}-\mathrm{kt}$

where: $C=$ vitamin $C$ concentration in function of storage time ( $\mathrm{mg} / 100 \mathrm{~g}$ powder); $C_{\mathrm{o}}=$ initial vitamin $\mathrm{C}$ concentration before storage (mg/100 g powder); $k=$ vitamin $\mathrm{C}$ degradation rate; $t=$ storage time $(\mathrm{h})$.

\subsection{Statistical analysis}

Statistical analyses were performed in triplicate and standard deviations were determined. This procedure was carried out using the SAS software (version 9.2) and the difference between the means (for each property) determined using Duncan's test.

\section{Results and discussion}

\subsection{Pulp characterization}

As expected, the vitamin $\mathrm{C}$ concentration of the camu-camu pulp was higher than that of the acerola pulp (Table 1), camu-camu being known as the Brazilian fruit with the highest percentage of vitamin C (CunhaSantos et al., 2018; Fracassetti et al., 2013; Maeda et al., 2007). Although acerola has lower concentration, it is higher compared to other fruits such as orange, lemon, or grapefruit (Elkhatim et al., 2018), as well as citrus 
fruits in general (Ramful et al., 2011), peach (Liu et al., 2015), araça, and cupuaçu (Contreras-Calderón et al., 2011). In fact, the measured concentration of vitamin $C$ in camu-camu exceeded the values reported in other studies (Gonçalves et al., 2014; Maeda et al., 2007; Neves et al., 2015; Silva et al., 2005). Neves et al. (2015) evaluated the antioxidant compounds of camu-camu pulp at different maturation stages, reporting a vitamin C concentration in fresh pulp of $4752.2 \mathrm{mg} / 100 \mathrm{~g}$. According to Cunha-Santos et al. (2018), the harvest region may influence the concentration of vitamin $\mathrm{C}$.

Table 1. Concentration of vitamin C, lightness $\left(L^{*}\right)$, chroma a $\left(a^{*}\right)$ and chroma $\mathrm{b}\left(b^{*}\right)$ of the acerola and camu-camu pulp.

\begin{tabular}{ccr}
\hline Analysis & Acerola pulp & Camu-camu pulp \\
\hline Vitamin C (mg / 100 g de pulp dry basis $)$ & $2063.8 \pm 137.9^{\mathrm{b}}$ & $6754.7 \pm 215.8^{\mathrm{a}}$ \\
\hline$L^{*}$ & $34.6 \pm 0.8^{\mathrm{b}}$ & $49.1 \pm 2.1^{\mathrm{a}}$ \\
\hline$a^{*}$ & $10.9 \pm 0.6^{\mathrm{a}}$ & $8.4 \pm 0.9^{\mathrm{b}}$ \\
\hline$b^{*}$ & $21.5 \pm 0.7^{\mathrm{a}}$ & $7.8 \pm 0.5^{\mathrm{b}}$ \\
\hline
\end{tabular}

Different letters in the same line indicate significant differences $(p<0.05)$ between the means.

Assis et al. (2001) evaluated vitamin C concentration in acerola pulp at different maturation stages and reported values in the range of 957 to $2424 \mathrm{mg} / 100 \mathrm{~g}$ of pulp. Mercali et al. (2014) reported that the initial concentration of vitamin C in the acerola pulp was $1657 \mathrm{mg} / 100 \mathrm{~g}$ of pulp, while Milani et al. (2015) reported that in natura, acerola pulp had a vitamin C content of $806 \mathrm{mg} / 100 \mathrm{~g}$ of pulp.

Rezende et al. (2017) evaluated different methods of extraction (agitation in shaker, storage in refrigerator, and ultrasound-assisted extraction) of acerola pulp active compounds and observed that ultrasound-assisted extraction resulted in higher vitamin C concentrations ( $489 \pm 26 \mathrm{mg} 100 \mathrm{~g}$ ).

Regarding the color parameters (Table 1), acerola and camu-camu pulp presented positive values for chroma $a^{*}$ and $b^{*}$, indicating a tendency towards red and yellow colors; with acerola having higher chroma $a^{*}$ values indicating a greater intensity of red color in comparison to camu-camu. Jaeschke et al. (2016) reported that acerola pulp had values of $L^{*}$ of 39.91 , chroma $a^{*}$ of 20.68 and $b^{*}$ of 25.06 , comparable to those reported in this study.

\subsection{Acerola and camu-camu powder characterization}

\subsubsection{Vitamin C concentration, hygroscopicity, water activity, and color parameters}

Vitamin $\mathrm{C}$ concentrations in the camu-camu powder were observed to be higher than those of acerola powder (Table 2), even using different maltodextrin concentrations to produce camu-camu $(15 \%)$ and acerola (5\%) powders. Comparing these results with those obtained for the pulp (Table 1), a reduction in vitamin $\mathrm{C}$ concentration of approximately $22.8 \%$ for the acerola powder and only $1 \%$ for the camu-camu powder was observed after the drying process, close to values reported in literature. The higher concentration of maltodextrin used in camu-camu powder production possibly favored protection of the vitamin during the drying process. According to Wang et al. (2015), maltodextrin possesses oxidation protection properties, offering higher encapsulation efficiency with lower oxygen permeability.

Table 2. Concentration of vitamin $\mathrm{C}$, hygroscopicity, water activity, moisture content, lightness $\left(L^{*}\right)$, chroma a $\left(a^{*}\right)$, chroma $\mathrm{b}\left(b^{*}\right)$ and antioxidant activity of acerola and camu-camu powders.

\begin{tabular}{|c|c|c|}
\hline Analysis & Acerola powder & Camu-camu powder \\
\hline Vitamin C (mg / $100 \mathrm{~g}$ of powders) & $1593.2 \pm 64.3^{\mathrm{b}}$ & $6690.4 \pm 137.6^{\mathrm{a}}$ \\
\hline Hygroscopicity ( $\mathrm{g}$ of $\mathrm{H}_{2} \mathrm{O} / 100 \mathrm{~g}$ of powder) & $78.1 \pm 2.5^{\mathrm{a}}$ & $44.1 \pm 4.1^{\mathrm{b}}$ \\
\hline Water activity & $0.25 \pm 0.01^{\mathrm{b}}$ & $0.37 \pm 0.01^{\mathrm{a}}$ \\
\hline Moisture content (g / $100 \mathrm{~g}$ dry powder) & $3.9 \pm 0.1^{\mathrm{a}}$ & $2.5 \pm 0.4^{\mathrm{b}}$ \\
\hline Color parameters & $65.4 \pm 1.2^{\mathrm{b}}$ & $79.9 \pm 1.1^{\mathrm{a}}$ \\
\hline
\end{tabular}




\begin{tabular}{|c|c|c|c|}
\hline \multicolumn{2}{|c|}{ Analysis } & \multirow{2}{*}{$\begin{array}{c}\text { Acerola powder } \\
15.1 \pm 0.1^{\mathrm{a}}\end{array}$} & \multirow{2}{*}{$\frac{\text { Camu-camu powder }}{7.7 \pm 0.3^{\mathrm{b}}}$} \\
\hline & $a^{*}$ & & \\
\hline & $b^{*}$ & $27.1 \pm 0.6^{\mathrm{a}}$ & $6.7 \pm 0.4^{b}$ \\
\hline \multirow{3}{*}{ Antioxidant activity } & $\operatorname{ABTS}^{\bullet+1}$ & $1423.4 \pm 32.6^{\mathrm{b}}$ & $4114.6 \pm 122.6^{\mathrm{a}}$ \\
\hline & $\mathrm{DPPH} \cdot\left(\mathrm{EC}_{50}\right)^{2}$ & $2.3 \pm 0.05^{\mathrm{a}}$ & $1.4 \pm 0.03^{b}$ \\
\hline & FRAP $^{3}$ & $5068.4 \pm 477.1^{\mathrm{b}}$ & $6283.4 \pm 385.7^{\mathrm{a}}$ \\
\hline
\end{tabular}

Different letters in the same line indicate significant differences $(p<0.05)$ between the means; ${ }^{1} \mathrm{ABTS}^{\bullet+}: \mu$ Mol of trolox equivalent $/ 100 \mathrm{~g}$ powders; ${ }^{2} \mathrm{DPPH}: \mathrm{mg} / \mathrm{mL} ;{ }^{3} \mathrm{FRAP}: \mu \mathrm{Mol}$ of trolox equivalent $/ 100 \mathrm{~g}$ powders.

The observed value of vitamin $\mathrm{C}$ concentration for the camu-camu powder (Table 2) was higher than those observed in literature. Souza et al. (2015) reported the concentration of vitamin $C$ in the camu-camu of $4630.1 \mathrm{mg} / 100 \mathrm{~g}$ powder obtained by spray drying using maltodextrin $(1: 2, \mathrm{w}: \mathrm{w})$. Rezende et al. (2018) evaluated the concentration of vitamin C in pulp and acerola microcapsules obtained by spray drying, observing a concentration of approximately $220 \mathrm{mg} / 100 \mathrm{~g}$, lower than those observed in this study (Table 2).

We verified that the hygroscopicity (Table 2 ) of the acerola powder was higher $\left(78.1 \mathrm{~g} \mathrm{H}_{2} \mathrm{O} / 100 \mathrm{~g}\right.$ ) than that of camu-camu, which may be due to the lower concentration of carrier agent $(5 \%)$ added for the production of the former. Tonon, Brabet, \& Hubinger (2008) produced açaí pulp microparticles by spray drying and observed reduced hygroscopicity values with higher carrier agent concentration.

Reduced values of water activity (Table 2 ) were observed for both powders (acerola and camucamu). Values of water activity between 0.20 and 0.40 ensure a good stability of stored microparticles against enzymatic and non-enzymatic reactions, as well as lipid oxidation (Singh \& Heldman, 1993). Bell \& Lapuza (1992) reported that microbial growth occurs in water activity ranges above 0.6 and 0.7 . Therefore, it can be affirmed that the acerola and camu-camu powders present good storage stability regarding microbial activity. Rezende et al. (2018) also observed values of water activity $<0.3$ for the acerola microparticles.

The acerola and camu-camu powders also presented a reduced moisture content (Table 2), highlighting the efficiency of the drying process. According to Oliveira \& Petrovick (2010), the drying variables must be controlled to obtain adequate yield and moisture content. The humidity of the acerola powder obtained by spray drying can vary from $3.09 \%$ to $5.43 \%$, depending on the amount of carrier agent added (Moreira et al., 2009).

Both powders showed increased luminosity $\left(L^{*}\right)$, while an increase in chroma values a* and $\mathrm{b}^{*}$ for acerola and reduction of these parameters (chroma $a^{*}$ and $b^{*}$ ) for camu-camu powder was observed, in comparison to the pulp (Table 1), indicating a tendency towards lighter red. According to Ferrari et al. (2012), maltodextrin possesses white coloration and, once added to the pulp during the drying process, can dilute the pigments present in the fruit, resulting in a lighter coloration. (Rezende et al., 2018) produced acerola pulp microcapsules, observing values for chroma $a^{*}$ and $b^{*}$ in the first quadrant, indicating the same tendency towards red color.

\subsubsection{Scanning electron microscopy}

In general, the drying of the acerola (Figure 1a) and camu-camu pulp (Figure 1b) led to the formation of spherical particles of different sizes, characteristic of powders obtained by spray drying. 


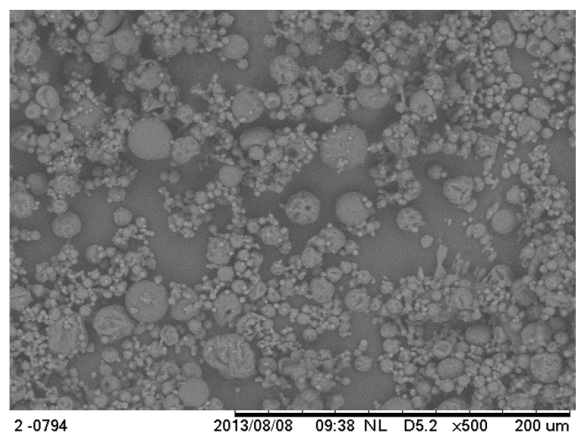

(a)

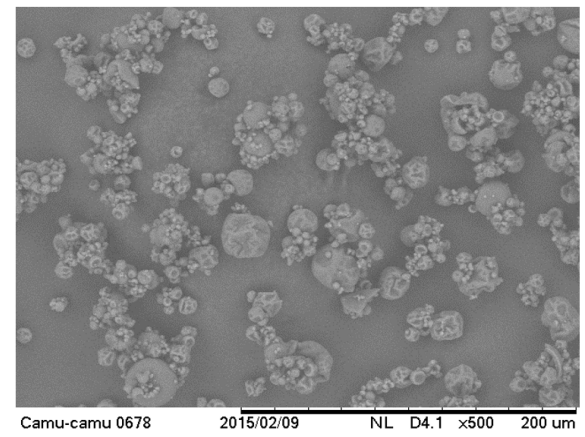

(b)

Figure 1. Micrographs of acerola (a) and camu-camu (b) powders obtained by spray drying with increase of 500x.

Tonon et al. (2009) observed the formation of spherical particles in the spray drying of açaí pulp, reporting that such shapes are characteristic of microparticles produced by this drying system. Dib Taxi et al. (2003) evaluated the spray drying process of camu-camu, also observing the formation of particles with different sizes and spherical form. Similar results were reported by Rezende et al. (2018), who evaluated the morphology of acerola microcapsules obtained by spray drying, observing that most samples presented irregular shapes, a smooth surface and spherical conformation, characteristic of microparticles produced by the spray drying process.

\subsection{Antioxidant capacity}

Table 2 shows the antioxidant capacity of the acerola and camu-camu powders. In general, the camu-camu powder had a more efficient antioxidant capacity compared to the acerola powder, possibly due to a higher concentration of vitamin $\mathrm{C}$ after the drying process (Table 2). In addition to vitamin $\mathrm{C}$ content, the antioxidant capacity of the camu-camu powder may also be related to the presence of compounds such as anthocyanins, ellagic acid derivatives, flavonols, and flavanones (Chirinos et al., 2010).

Mezadri et al. (2008) evaluated the antioxidant capacity of acerola in natura and commercial pulp and acerola juice, reporting a high antioxidant activity in vitro for the evaluated methods (ABTS ${ }^{\bullet+}, \mathrm{DPPH} \bullet \mathrm{e}$ ORAC), with vitamin C being responsible for $40 \%$ to $83 \%$ of antioxidant activity. Fracassetti et al. (2013) evaluated the antioxidant capacity of $10 \%$ maltodextrin spray dried powder of camu-camu and reported 167.5 $\mu \mathrm{Mol}$ of trolox equivalent/100 g powder according to $\mathrm{ABTS}^{\bullet+}$ assay, showing camu-camu powder to be a good source of potentially bioactive compounds beneficial to health.

\subsection{Stability of vitamin C in the acerola and camu-camu powders}

In general, differences between the vitamin $\mathrm{C}$ concentrations of the acerola and camu-camu powders were observed for the different storage conditions (Figure 2). For the same storage period (30 days), at $30{ }^{\circ} \mathrm{C}$ and $75 \% \mathrm{RH}$, the vitamin $\mathrm{C}$ content was reduced by $77.8 \%$ in acerola powder, while decreasing by only $39.5 \%$ for camu-camu powder. A similar effect was observed for $40{ }^{\circ} \mathrm{C}$ for the same period, whereby the vitamin $\mathrm{C}$ content was reduced by $91.3 \%$ in acerola powder and $57.1 \%$ in camu-camu powder, indicating a higher vitamin $\mathrm{C}$ degradation rate during storage for acerola powder.

Hoyos-Leyva et al. (2018) evaluated the stability of vitamin C microencapsulates in taro starch by spray drying in different relative humidity, observing higher instability of vitamin $\mathrm{C}$ at higher relative humidity (72\%). In addition to the lower initial concentration of vitamin $\mathrm{C}$ in the acerola powder, another factor that may be associated with greater stability of the camu-camu powder is the concentration of maltodextrin. Dib Taxi et al. (2003) reported that the use of maltodextrin as a carrier agent is efficient for the conservation of vitamin $\mathrm{C}$ during the drying process, indicating efficiency in the microencapsulation process. Righetto \& 
Maria Netto (2005) also verified efficiency in the use of maltodextrin as an encapsulating agent in acerola juice.

In addition to temperature, the increased water activity and moisture content of the powder caused by the high relative humidity of storage $(75 \% \mathrm{HR})$, may also be associated with the degradation rate of vitamin C.
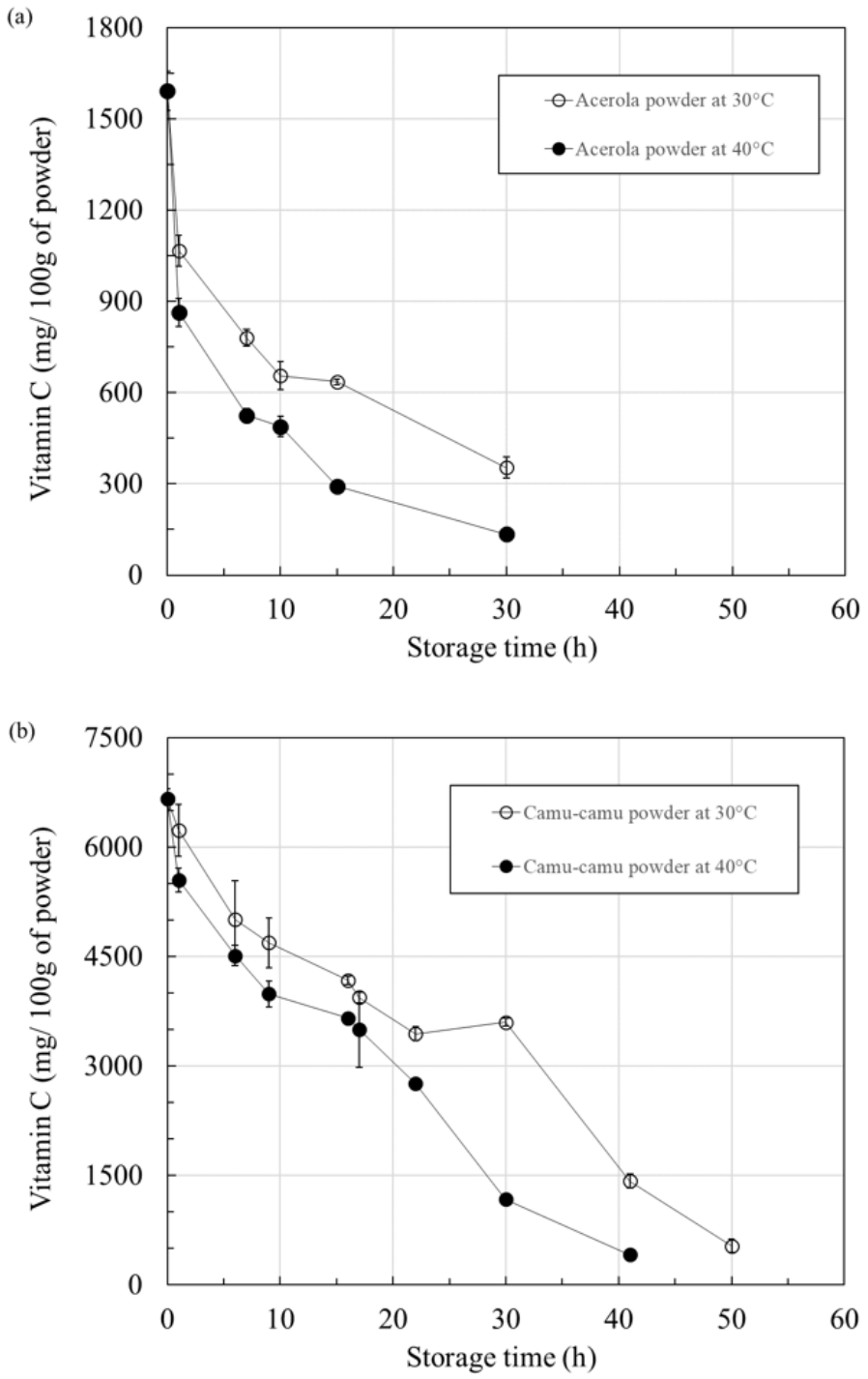

Figure 2. Vitamin $\mathrm{C}$ concentration during storage as a function of temperature $\left(30^{\circ} \mathrm{C}\right.$ and $\left.40{ }^{\circ} \mathrm{C}\right)$ and relative humidity (75\%): (a) acerola and (b) camu-camu powder.

The vitamin $\mathrm{C}$ concentration of the acerola and camu-camu powders over time presented a similar behavior profile at both considered temperatures (Figure 2). On the other hand, when the degradation kinetics of vitamin $\mathrm{C}$ were evaluated using the 1st order model (see section 2.6 for more details), the calculated vitamin $\mathrm{C}$ degradation rate parameters for acerola and camu-camu powders stored at $40^{\circ} \mathrm{C}$ and relative humidity of $75 \%$ were higher than those calculated for degradation at $30{ }^{\circ} \mathrm{C}$ (Table 3 ). Possibly, the temperature negatively influenced the vitamin $\mathrm{C}$ content of the powders since the degradation rates increased with temperature. Comunian et al. (2013) evaluated the stability of encapsulated vitamin $\mathrm{C}$ stored at $20^{\circ} \mathrm{C}$ and $37^{\circ} \mathrm{C}$, observing a higher degradation rate at $37{ }^{\circ} \mathrm{C}$, indicating a negative effect of temperature on the stability of the encapsulated vitamin $\mathrm{C}$. 
Table 3. Degradation rate of acerola and camu-camu powders stored at different temperatures and relative humidity of $75 \%$.

\begin{tabular}{cccc}
\hline Powders & Temperature $\left({ }^{\circ} \mathbf{C}\right)$ & $\boldsymbol{K}\left(\mathbf{h}^{-1}\right)$ & $\mathbf{R}^{\mathbf{2}}$ \\
\hline \multirow{2}{*}{ Acerola } & 30 & -0.044 & 0.89 \\
\cline { 2 - 4 } & 40 & -0.074 & 0.92 \\
\hline \multirow{2}{*}{ Camu-camu } & 30 & -0.043 & 0.87 \\
\cline { 2 - 4 } & 40 & -0.061 & 0.92 \\
\hline
\end{tabular}

Trindade \& Grosso (2000) studied the microencapsulation process of vitamin C by spray drying using rice starch, gelatin, and gum arabic as carrier agents, reporting a relatively stable vitamin $\mathrm{C}$ concentration at 21 ${ }^{\circ} \mathrm{C}$ in $60 \%$ relative humidity for gum arabic, but a reduction of this parameter when temperature was increased to $45^{\circ} \mathrm{C}$.

\section{Conclusion}

The acerola and camu-camu powders produced by spray drying presented excellent stability characteristics (water activity and moisture) and antioxidant properties. At a temperature of $40{ }^{\circ} \mathrm{C}$ a higher vitamin $\mathrm{C}$ degradation rate than at $30{ }^{\circ} \mathrm{C}$ was observed. The suitability of acerola and camu-camu powders, due to their high concentration of vitamin $\mathrm{C}$ and stability, for use in different industrial applications has been demonstrated.

\section{Acknowledgements}

The authors would like to thank the São Paulo Research Foundation (FAPESP, 2013/03143-7) and National Council for Scientific and Technological Development (CNPq) for the scholarship V. A. S. Garcia and productivity grant (307143/2013-9) for the R. A. Carvalho, respectively.

\section{References}

Akter, M. S., Oh, S., Eun, J. B., \& Ahmed, M. (2011). Nutritional compositions and health promoting phytochemicals of camucamu (Myrciaria dubia) fruit: a review. Food Research International, 44(7), 1728-1732. http://dx.doi.org/10.1016/j.foodres.2011.03.045

Assis, S. A., Lima, D. C., \& De Faria Oliveira, O. M. M. (2001). Activity of pectinmethylesterase, pectin content and vitamin C in acerola fruit at various stages of fruit development. Food Chemistry, 74(2), 133-137. http://dx.doi.org/10.1016/S03088146(01)00104-2

Azevêdo, J. C. S., Borges, K. C., Genovese, M. I., Correia, R. T. P., \& Vattem, D. A. (2015). Neuroprotective effects of dried camu-camu (Myrciaria dubia HBK McVaugh) residue in C. elegans. Food Research International, 73, 135-141. http://dx.doi.org/10.1016/j.foodres.2015.02.015

Azevêdo, J. C. S., Fujita, A., Oliveira, E. L., Genovese, M. I., \& Correia, R. T. P. (2014). Dried camu-camu (Myrciaria dubia H.B.K. McVaugh) industrial residue: a bioactive-rich Amazonian powder with functional attributes. Food Research International, 62, 934-940. http://dx.doi.org/10.1016/j.foodres.2014.05.018

Bastos, C. T. R. M., Ladeira, T. M. S., Rogez, H., \& Pena, H. S. (2008). Estudo da eficiência da pasteurização da polpa de taperebá (Spondias Mombin). Alimentos e Nutrição, 19, 123-131.

Bell, L. N., \& Lapuza, T. P. (1992). Composition influence on the pH of reduced-moisture solutions. Journal of Food Science, 57, 732-734.

Belwal, T., Devkota, H. P., Hassan, H. A., Ahluwalia, S., Ramadan, M. F., Mocan, A., \& Atanasov, A. G. (2018). Trends in food science \& technology phytopharmacology of Acerola (Malpighia spp.) and its potential as functional food. Trends in Food Science \& Technology, 74(February), 99-106. http://dx.doi.org/10.1016/j.tifs.2018.01.014

Benzie, I. F. F., \& Strain, J. J. (1996). The Ferric Reducing Ability of Plasma (FRAP) as a measure of 'antioxidant power': the FRAP Assay. Analytical Biochemistry, 239(1), 70-76. PMid:8660627. http://dx.doi.org/10.1006/abio.1996.0292

Bhusari, S. N., Muzaffar, K., \& Kumar, P. (2014). Effect of carrier agents on physical and microstructural properties of spray dried tamarind pulp powder. Powder Technology, 266, 354-364. http://dx.doi.org/10.1016/j.powtec.2014.06.038 
Brand-Williams, W., Cuvelier, M. E., \& Berset, C. (1995). Use of a free radical method to evaluate antioxidant activity. Lebensmittel-Wissenschaft + Technologie, 30(1), 25-30. http://dx.doi.org/10.1016/S0023-6438(95)80008-5

Brito, E. S., Araújo, M. C. P., Alves, R. E., Carkeet, C., Clevidence, B. A., \& Novotny, J. A. (2007). Anthocyanins present in selected tropical fruits: acerola, jambolão, jussara, and guajiru. Journal of Agricultural and Food Chemistry, 55(23), 9389-9394. PMid:17929888. http://dx.doi.org/10.1021/jf0715020

Cai, Y. Z., \& Corke, H. (2000). Production and properties of biochar. Sensory and Nutritive Qualities of Food Production, 65(3600), 1248-1252. Retrieved in 2019, August 30, from https://brage.bibsys.no/xmlui/handle/11250/2496306

Chirinos, R., Galarza, J., Betalleluz-Pallardel, I., Pedreschi, R., \& Campos, D. (2010). Antioxidant compounds and antioxidant capacity of Peruvian camu-camu (Myrciaria dubia (H.B.K.) McVaugh) fruit at different maturity stages. Food Chemistry, 120(4), 1019-1024. http://dx.doi.org/10.1016/j.foodchem.2009.11.041

Comunian, T. A., Thomazini, M., Alves, A. J. G., Matos Junior, F. E., Carvalho Balieiro, J. C., \& Favaro-Trindade, C. S. (2013). Microencapsulation of ascorbic acid by complex coacervation: protection and controlled release. Food Research International, 52(1), 373-379. http://dx.doi.org/10.1016/j.foodres.2013.03.028

Contreras-Calderón, J., Calderón-Jaimes, L., Guerra-Hernández, E., \& García-Villanova, B. (2011). Antioxidant capacity, phenolic content and vitamin C in pulp, peel and seed from 24 exotic fruits from Colombia. Food Research International, 44(7), 2047-2053. http://dx.doi.org/10.1016/j.foodres.2010.11.003

Cunha-Santos, E. C. E., Viganó, J., Neves, D. A., Martínez, J., \& Godoy, H. T. (2018). Vitamin C in camu-camu [Myrciaria dubia (H.B.K.) McVaugh]: evaluation of extraction and analytical methods. Food Research International, 0-1(Aug), PMid:30599928. http://dx.doi.org/10.1016/j.foodres.2018.08.031

Daud, A., Bonde, M., \& Sapkal, N. (2011). Development of Zingiber officinale in oral dissolving films: effect of polymers on in vitro, in vivoparameters and clinical efficacy. Asian Journal of Pharmaceutics, 20(3), 443-448. http://dx.doi.org/10.4103/09738398.91995

Dib Taxi, C. M. A., Menezes, H. C., Santos, A. B., \& Grosso, C. R. F. (2003). Study of the microencapsulation of camu-camu (Myrciaria dubia) juice. Journal of Microencapsulation, 20(4), 443-448. PMid:12851044. http://dx.doi.org/10.1080/0265204021000060291

Elkhatim, K. A. S., Elagib, R. A. A., \& Hassan, A. B. (2018). Content of phenolic compounds and vitamin C and antioxidant activity in wasted parts of Sudanese citrus fruits. Food Science \& Nutrition, 6(5), 1214-1219. PMid:30065822. http://dx.doi.org/10.1002/fsn3.660

Ellingsen, I., Seljeflot, I., Arnesen, H., \& Tonstad, S. (2009). Vitamin C consumption is associated with less progression in carotid intima media thickness in elderly men: a 3-year intervention study. Nutrition, Metabolism, and Cardiovascular Diseases, 19(1), 8-14. PMid:18472409. http://dx.doi.org/10.1016/j.numecd.2008.01.006

Fennema, O. R., Parkin, K. L., \& Damodaran, S. (2010). Química de Alimentos de Fennema (1095 p.). Porto Alegre: Artmed

Fernandes, F. A. N., Santos, V. O., \& Rodrigues, S. (2019). Effects of glow plasma technology on some bioactive compounds of acerola juice. Food Research International, 115, 16-22. PMid:30599927. http://dx.doi.org/10.1016/j.foodres.2018.07.042

Ferrari, C. C., Ribeiro, C. P., \& Aguirre, J. M. (2012). Spray drying of blackberry pulp using maltodextrin as carrier agent. Brazilian Journal of Food Technology, 15(2), 157-165. http://dx.doi.org/10.1590/S1981-67232012005000009

Fidelis, M., do Carmo, M. A. V., Cruz, T. M., Azevedo, L., Myoda, T., Miranda Furtado, M., Boscacci Marques, M., Sant'Ana, A. S., Inês Genovese, M., Young Oh, W., Wen, M., Shahidi, F., Zhang, L., Franchin, M., Alencar, S. M., Luiz Rosalen, P., \& Granato, D. (2019). Camu-camu seed (Myrciaria dubia) - From side stream to an antioxidant, antihyperglycemic,

antiproliferative, antimicrobial, antihemolytic, anti-inflammatory, and antihypertensive ingredient. Food Chemistry, 310, 125909. PMid:31816536. http://dx.doi.org/10.1016/j.foodchem.2019.125909

Fidelis, M., Santos, J. S., Escher, G. B., Carmo, M. V., Azevedo, L., Silva, M. C., Putnik, P., \& Granato, D. (2018). In vitro antioxidant and antihypertensive compounds from camu-camu (Myrciaria dubia McVaugh, Myrtaceae) seed coat: a multivariate structure-activity study. Food and Chemical Toxicology, 120(July), 479-490. PMid:30055315.

http://dx.doi.org/10.1016/j.fct.2018.07.043

Findik, R. B., Ilkaya, F., Guresci, S., Guzel, H., Karabulut, S., \& Karakaya, J. (2016). Effect of vitamin C on collagen structure of cardinal and uterosacral ligaments during pregnancy. European Journal of Obstetrics, Gynecology, and Reproductive Biology, 201, 31-35. PMid:27042769. http://dx.doi.org/10.1016/j.ejogrb.2016.03.022

Fracassetti, D., Costa, C., Moulay, L., \& Tomás-Barberán, F. A. (2013). Ellagic acid derivatives, ellagitannins, proanthocyanidins and other phenolics, vitamin $\mathrm{C}$ and antioxidant capacity of two powder products from camu-camu fruit (Myrciaria dubia). Food Chemistry, 139(1-4), 578-588. PMid:23561148. http://dx.doi.org/10.1016/j.foodchem.2013.01.121

Fujita, A., Borges, K., Correia, R., Franco, B. D. G. M., \& Genovese, M. I. (2013). Impact of spouted bed drying on bioactive compounds, antimicrobial and antioxidant activities of commercial frozen pulp of camu-camu (Myrciaria dubia Mc. Vaugh). Food Research International, 54(1), 495-500. http://dx.doi.org/10.1016/j.foodres.2013.07.025

Fujita, A., Souza, V. B., Daza, L. D., Fávaro-Trindade, C. S., Granato, D., \& Genovese, M. I. (2017). Effects of spray-drying parameters on in vitro functional properties of camu-camu (Myrciaria dubia Mc. Vaugh): a typical amazonian fruit. Journal of Food Science, 82(5), 1083-1091. PMid:28329408. http://dx.doi.org/10.1111/1750-3841.13668

Gonçalves, A. E. S. S., Lellis-Santos, C., Curi, R., Lajolo, F. M., \& Genovese, M. I. (2014). Frozen pulp extracts of camu-camu (Myrciaria dubia McVaugh) attenuate the hyperlipidemia and lipid peroxidation of Type 1 diabetic rats. Food Research International, 64, 1-8. PMid:30011628. http://dx.doi.org/10.1016/j.foodres.2014.05.074

Han, R., Liu, L., Li, J., Du, G., \& Chen, J. (2012). Functions, applications and production of 2-O-D-glucopyranosyl-L-ascorbic acid. Applied Microbiology and Biotechnology, 95(2), 313-320. PMid:22639144. http://dx.doi.org/10.1007/s00253-012-4150-9 
Hoyos-Leyva, J. D., Chavez-Salazar, A., Castellanos-Galeano, F., Bello-Perez, L. A., \& Alvarez-Ramirez, J. (2018). Physical and chemical stability of L-ascorbic acid microencapsulated into taro starch spherical aggregates by spray drying. Food Hydrocolloids, 83, 143-152. http://dx.doi.org/10.1016/j.foodhyd.2018.05.002

Jaeschke, D. P., Marczak, L. D., \& Mercali, G. D. (2016). Evaluation of non-thermal effects of electricity on ascorbic acid and carotenoid degradation in acerola pulp during ohmic heating. Food Chemistry, 199, 128-134.

http://dx.doi.org/10.1016/j.foodchem.2015.11.117

Liu, H., Cao, J., \& Jiang, W. (2015). Evaluation and comparison of vitamin C, phenolic compounds, antioxidant properties and metal chelating activity of pulp and peel from selected peach cultivars. Lebensmittel-Wissenschaft + Technologie, 63(2), 10421048. http://dx.doi.org/10.1016/j.lwt.2015.04.052

Maeda, R. N., Pantoja, L., Yuyama, L. K. O., \& Chaar, J. M. (2007). Estabilidade de ácido ascórbico e antocianinas em néctar de camu-camu (Myrciaria dubia (H. B. K.) McVaugh). Food Science and Technology (Campinas), 27(2), 313-316. http://dx.doi.org/10.1590/S0101-20612007000200018

Malegori, C., Marques, E. J. N., Freitas, S. T., Pimentel, M. F., Pasquini, C., \& Casiraghi, E. (2017). Comparing the analytical performances of Micro-NIR and FT-NIR spectrometers in the evaluation of acerola fruit quality, using PLS and SVM regression algorithms. Talanta, 165(1), 112-116. PMid:28153229. http://dx.doi.org/10.1016/j.talanta.2016.12.035

Marques, L. G., Prado, M. M., \& Freire, J. T. (2009). Rehydration characteristics of freeze-dried tropical fruits. Lebensmitte/Wissenschaft + Technologie, 42(7), 1232-1237. http://dx.doi.org/10.1016/j.Iwt.2009.02.012

Mercali, G. D., Jaeschke, D. P., Tessaro, I. C., \& Marczak, L. D. F. (2012). Study of vitamin C degradation in acerola pulp during ohmic and conventional heat treatment. Lebensmittel-Wissenschaft + Technologie, 47(1), 91-95.

http://dx.doi.org/10.1016/j.Iwt.2011.12.030

Mercali, G. D., Schwartz, S., Marczak, L. D. F., Tessaro, I. C., \& Sastry, S. (2014). Ascorbic acid degradation and color changes in acerola pulp during ohmic heating: effect of electric field frequency. Journal of Food Engineering, 123, 1-7.

http://dx.doi.org/10.1016/j.jfoodeng.2013.09.011

Mezadri, T., Villaño, D., Fernández-Pachón, M. S., García-Parrilla, M. C., \& Troncoso, A. M. (2008). Antioxidant compounds and antioxidant activity in acerola (Malpighia emarginata DC.) fruits and derivatives. Journal of Food Composition and Analysis, 21(4), 282-290. http://dx.doi.org/10.1016/j.jfca.2008.02.002

Milani, P. G., Prato, A. M., Monteiro, A. R. G., Maioral, M. F., Marchi, L. B., \& Costa, S. C. (2015). Assessment of operating parameters, membrane fouling and juice quality during acerola ultrafiltration. Chemical Engineering Transactions, 44, 325-330. http://dx.doi.org/10.3303/CET1544055.

Moreira, G. É. G., Maia Costa, M. G., Souza, A. C. R., Brito, E. S., \& Medeiros, M. (2009). Physical properties of spray dried acerola pomace extract as affected by temperature and drying aids. Lebensmittel-Wissenschaft + Technologie, 42(2), 641-645. http://dx.doi.org/10.1016/j.Iwt.2008.07.008

Müller, L., Gnoyke, S., Popken, A. M., \& Böhm, V. (2010). Antioxidant capacity and related parameters of different fruit formulations. Lebensmittel-Wissenschaft + Technologie, 43(6), 992-999. http://dx.doi.org/10.1016/j.Iwt.2010.02.004

Neves, L. C., Silva, V. X., Pontis, J. A., Flach, A., \& Roberto, S. R. (2015). Bioactive compounds and antioxidant activity in preharvest camu-camu [Myrciaria dubia (H.B.K.) Mc Vaugh] fruits. Scientia Horticulturae, 186, 223-229. http://dx.doi.org/10.1016/j.scienta.2015.02.031

Oliveira, O. W., \& Petrovick, P. R. (2010). Secagem por aspersão (spray drying) de extratos vegetais: bases e aplicações. Revista Brasileira de Farmacologia, 20, 641-650. http://dx.doi.org/10.1590/S0102-695X2010000400026

Padayatty, S. J., \& Levine, M. (2016). Vitamin C: the known and the unknown and Goldilocks. Oral Diseases, 22(6), 463-493. PMid:26808119. http://dx.doi.org/10.1111/odi.12446

Pereira, C. G., de Resende, J. V., \& Giarola, T. M. O. (2014). Relationship between the thermal conductivity and rheological behavior of acerola pulp: effect of concentration and temperature. Lebensmittel-Wissenschaft + Technologie, 58(2), 446-453. http://dx.doi.org/10.1016/j.Iwt.2014.04.016

Podmore, I. D., Griffiths, H. R., Herbert, K. E., Mistry, N., Mistry, P., \& Lunec, J. (1998). Vitamin C exhibits pro-oxidant properties. Nature, 392(Apr), 559. PMid:9560150.

Ramful, D., Tarnus, E., Aruoma, O. I., Bourdon, E., \& Bahorun, T. (2011). Polyphenol composition, vitamin C content and antioxidant capacity of Mauritian citrus fruit pulps. Food Research International, 44(7), 2088-2099. http://dx.doi.org/10.1016/j.foodres.2011.03.056

Re, R., Pellegrini, N., Proteggente, A., Pannala, A., Yang, M., \& Rice-Evans, C. (1999). Antioxidant activity applying an improved ABTS radical cation decolorization assay. Free Radical Biology \& Medicine, 26(9-10), 1231-1237. PMid:10381194. http://dx.doi.org/10.1016/S0891-5849(98)00315-3

Rezende, Y. R. R. S., Nogueira, J. P., \& Narain, N. (2017). Comparison and optimization of conventional and ultrasound assisted extraction for bioactive compounds and antioxidant activity from agro-industrial acerola (Malpighia emarginata DC) residue. Lebensmittel-Wissenschaft + Technologie, 85, 158-169. http://dx.doi.org/10.1016/j.Iwt.2017.07.020

Rezende, Y. R. R. S., Nogueira, J. P., \& Narain, N. (2018). Microencapsulation of extracts of bioactive compounds obtained fromacerola (Malpighia emarginataDC) pulp and residue by spray and freezedrying: chemical, morphological and chemometric characterization. Food Chemistry, 254, 281-291. PMid:29548455. http://dx.doi.org/10.1016/j.foodchem.2018.02.026

Righetto, A. M., \& Maria Netto, F. (2005). Effect of encapsulating materials on water sorption, glass transition and stability of juice from immature acerola. International Journal of Food Properties, 8(2), 337-346. http://dx.doi.org/10.1081/JFP-200060262 
Rufino, M., Alves, R. E., Brito, E. S., Pérez-Jiménez, J., Saura-Calixto, F., \& Mancini-Filho, J. (2010). Bioactive compounds and antioxidant capacities of 18 non-traditional tropical fruits from Brazil. Food Chemistry, 121(4), 996-1002.

http://dx.doi.org/10.1016/j.foodchem.2010.01.037

Sagar, V. R., \& Suresh Kumar, P. (2010). Recent advances in drying and dehydration of fruits and vegetables: A review. Journal of Food Science and Technology, 47(1), 15-26. PMid:23572596. http://dx.doi.org/10.1007/s13197-010-0010-8

Santos, L. M. L., Muniz, J. L., Pires, A. P. M., \& Araújo, R. S. (2014). Microencapsulação de ácido ascórbico em pó de acerola verde obtido por spray drying. In COBEQ - XX Congresso Brasileiro de Engenharia Química (Vol. 1, No. 2, pp. 3687-3694). São Paulo: Blucher. http://dx.doi.org/10.5151/chemeng-cobeq2014-0559-24953-182519.

Silva, M. A., Pinedo, R. A., \& Kieckbusch, G. (2005). Ascorbic acid thermal degradation during hot air drying of camu-camu (Myrciaria dubia [ H. B. K. ] McVaugh) slices at different air temperatures. Drying Technology, 23(9-11), 2277-2287. http://dx.doi.org/10.1080/07373930500212784

Silva, P. B., Duarte, C. R., \& Barrozo, M. A. S. (2016). Dehydration of acerola (Malpighia emarginata D.C.) residue in a new designed rotary dryer: effect of process variables on main bioactive compounds. Food and Bioproducts Processing, 98, 62-70. http://dx.doi.org/10.1016/j.fbp.2015.12.008

Singh, R. P., \& Heldman, D. R. (1993). Introduction to Food Engineering (2nd ed.). San Diego, California: Academic Press Inc..

Souza, A. L. R., Gomes, F. S., Tonon, R. V., Nogueira, R. I., Pontes, S. M., \& Cabral, L. M. C. (2015). Characterization and stability of vitamin C, phenolic compounds and antioxidant activity of the camu-camu juice microencapsulated. Journal of Fruits and Vegetables, 1(1), 35-38.

Tonon, R. V., Brabet, C., \& Hubinger, M. D. (2008). Influence of process conditions on the physicochemical properties of açai (Euterpe oleraceae Mart.) powder produced by spray drying. Journal of Food Engineering, 88(3), 411-418. http://dx.doi.org/10.1016/j.jfoodeng.2008.02.029

Tonon, R. V., Brabet, C., \& Hubinger, M. D. (2009). Influence of drying air temperature and carrier agent concentration on the physicochemical properties of açai juice powder. Food Science and Technology (Campinas), 29(2), 444-450. http://dx.doi.org/10.1590/S0101-20612009000200034

Trindade, M. A., \& Grosso, C. R. F. (2000). The stability of ascorbic acid microencapsulated in granules of rice starch and in gun Arabic. Journal of Microencapsulation, 17, 169-176. http://dx.doi.org/10.1080/026520400288409

Vikram, V. B., Ramesh, M. N., \& Prapulla, S. G. (2005). Thermal degradation kinetics of nutrients in orange juice heated by electromagnetic and conventional methods. Journal of Food Engineering, 69, 31-40. https://doi.org/10.1016/j.jfoodeng.2004.07.013

Wang, X., Yuan, Y., \& Yue, T. (2015). The application of starch-based ingredients in flavor encapsulation. Stärke, 67, 225-236. https://doi.org/10.1002/star.201400163

Funding: São Paulo Research Foundation (FAPESP, 2013/03143-

7) and National Council for Scientific and Technological Development (CNPq) (307143/2013-9). 